\title{
Comparative analysis of Vibrio splendidus-related strains isolated during Crassostrea gigas mortality events
}

\author{
Frédérique Le Roux ${ }^{\mathrm{a}, *}$, Mélanie Gay ${ }^{\mathrm{a}}$, Christophe Lambert ${ }^{\mathrm{b}}$, Magali Waechter ${ }^{\mathrm{c}}$, \\ Saravanne Poubalanne ${ }^{a}$, Bruno Chollet ${ }^{\text {a }}$, Jean-Louis Nicolas ${ }^{d}$, Franck Berthe ${ }^{\text {a }}$ \\ ${ }^{a}$ Laboratoire de Génétique et Pathologie, Ifremer, 17390 La Tremblade, France \\ ${ }^{\mathrm{b}}$ Laboratoire des Sciences de l'Environnement marin (LEMAR), Institut Universitaire Européen de la Mer (IUEM), \\ Université de Bretagne Occidentale (UBO), Place Copernic, technopole Brest-Iroise, 29280 Plouzané, France \\ 'Écloserie Grainocéan, 14 cours Dechézeaux, 17410 Saint Martin de Ré, France \\ ${ }^{\mathrm{d}}$ Laboratoire de Physiologie des Invertébrés marins, Ifremer, 29280 Plouzané, France
}

Received 8 October 2001; accepted 29 May 2002

\begin{abstract}
French mollusc production is based mainly on the Pacific cupped oyster, Crassostrea gigas. Since 1991, annual mass mortality of juveniles has been reported during summer months. These recurring episodes concern professionals who fear that like Portugese oyster, $C$. angulata, C. gigas could in turn disappear following one of these epizooties. Previously, bacteriological analysis of moribund oyster juveniles yielded an isolate of a Vibrio splendidus biovar II strain, named TNEMF6. This isolate was demonstrated to be pathogenic to Crassostrea gigas spat by experimental challenge. To study the association between summer oyster mortality and presence of TNEMF6 cluster strains, Vibrionaceae fauna were isolated from infected spat along the French Atlantic coast between 1997-1998. Strains related to V. splendidus biovar II were selected. Comparison with TNEMF6 was performed by classical biochemical tests and polymerase chain reaction - restriction fragment length polymorphism (PCR-RFLP) of SSU rDNA, rpoD, and gyrB genes. Genomic similarities were confirmed by DNA/DNA hybridization. Only one strain out of 14, TNNIII7, was found to be closely related to the pathogenic bacteria. Neither the phenotypic nor the genotypic markers used in this study were able to distinguish pathogenic from non-pathogenic strains of the widespread V. splendidus. However, future genetic comparisons of TNEMF6 and TNNIII7 is likely to reveal genes involved in pathogenicity. (C) 2002 Ifremer/CNRS/Inra/IRD/Cemagref/Éditions scientifiques et médicales Elsevier SAS. All rights reserved.
\end{abstract}

\section{Résumé}

Comparaison de souches apparentées à Vibrio splendidus biovar II isolées lors d'épisodes de mortalité d'huîtres creuses Crassostrea gigas. La production française de mollusques est principalement basée sur la culture d'huîtres creuses Crassostrea gigas. Depuis 1991, en période estivale, de forts taux de mortalité de naissain d'huîtres creuses sont observés régulièrement en milieu naturel et en écloseries. Ces épisodes récurrents inquiètent les professionnels qui craignent qu'à l'instar de l'huître portugaise, $C$. angulata, $C$. gigas puisse disparaître à son tour, suite à une épizootie. Différentes souches bactériennes appartenant au genre Vibrio ont été associées à des mortalités de mollusques. Récemment, nous avons isolé une souche Vibrio splendidus biovar II, TNEMF6, pathogène de naissain d'huître creuse. Dans ce travail, nous avons recherché la présence de cette souche dans d'autres épisodes de mortalité estivale. La flore vibrionacée d'animaux sains et moribonds a été isolée et les souches apparentées à Vibrio splendidus biovar II ont été sélectionnées. Une comparaison des souches a été effectuée par phénotypage (39 tests biochimiques) et génotypage (PCR-RFLP SSU rDNA, rpoD et gyrB). Les homologies génomiques ont été confirmées par hybridation ADN/ADN. Seule, une souche sur 14, apparait proche de ce vibrio pathogène. Cependant, les techniques phénotypiques et génotypiques utilisées dans ce travail ne permettent pas de distinguer les isolats pathogènes et non pathogènes. Cependant, les deux souches TNEMF6 et TNNIII7 vont être utilisées dans une approche de génomique comparative pour l'étude des supports moléculaires de la virulence. (C) 2002 Ifremer/CNRS/Inra/IRD/Cemagref/Éditions scientifiques et médicales Elsevier SAS. Tous droits réservés.

Keywords: Oyster mortality; PCR-RFLP; Epidemiology; Virulence; Vibrio splendidus

\footnotetext{
* Corresponding author.

E-mail address: fleroux@ifremer.fr (F. Le Roux).
} 


\section{Introduction}

Currently, French shellfish production is based mainly on the Pacific cupped oyster, Crassostrea gigas (130 000 t. $\left.^{-1}\right)$. The spat used in oyster farms are traditionally collected from natural sites ; however hatchery production contributes approximately 10 to $15 \%$ of the total spat production.

Since 1991, and principally during summer as the water temperature increases, recurrent $C$. gigas spat mortality (60 to $100 \%$ ) has occurred in the field and in hatcheries. Summer mortality is a major concern for the world's oyster industry. Studies indicate a complex etiology including several factors: environmental conditions, infectious agent, physiology and genetic of the host (Goulletquer et al., 1998).

Several bacterial strains, mainly Vibrio sp., have been recognized as pathogenic for bivalve species including the Pacific oyster (Elston and Leibovitz, 1980; Brown, 1981; Jeffries, 1982; Hada et al., 1984; Elston et al., 1987; Dungan et al., 1989; Sugumar et al., 1998; Lacoste et al., 2001). Since 1995, we have studied bacterial strains associated with oyster mortality. A strain isolated from wild spat sampled during a mortality outbreak, TNEMF6, was demonstrated to be pathogenic by experimental exposure of spat to a bacterial suspension. This strain was identified by phenotypic and genotypic characteristics as Vibrio splendidus biovar II (Waechter et al., 2002).

In the present work, we studied the association between mortality outbreaks and presence of TNEMF6. Strains of the genus Vibrio were isolated during oyster mortality outbreaks occurring along the French coast. Vibrio splendidus biovar II strains were selected on the basis of their phenotype. Comparison between selected Vibrio and TNEMF6 was performed by biochemical testing and genotyping.

In the modern taxonomy of bacteria, the phylogenetic analysis of SSU rRNA gene sequences is a standard method to investigate phylogenetic relationships among organisms. However, the clustering of strains based on SSU rDNA sequences are not always correlated with the degree of DNA homology determined by DNA/DNA hybridization which has been used as the benchmark criterion for the definition of bacterial species (Fox et al., 1992; Stackebrandt and Goebel, 1994). To resolve the phylogenetic relationships of closely related organisms, sequences of another gene than the SSU rRNA gene must be chosen to have a higher resolution. Phylogenetic analysis using the genes $\operatorname{gyr} B$ and rpoD sequences was shown to provide higher resolution than the one using the SSU rDNA sequence (Yamamoto and Harayama, 1998). Here we performed polymerase chain reaction and restriction fragment length polymorphism (PCR-RFLP) on SSU rDNA, rpoD and gyrB to genotype the Vibrio splendidus biovar II related strains. Results were confirmed by DNA/DNA hybridization. Selected strains were then tested for their pathogenic abilities after injection to oysters (C. gigas) and clams (Ruditapes philippinarum).

\section{Material and methods}

\subsection{Reference strains}

Vibrio splendidus biovar II strain TNEMF6, was deposited in the "Collection Nationale de Cultures de Microorganismes" (CNCM) of the Pasteur Institute as accession number I-2385 the 24 February 2000.

Two reference strains are included in this study: $V$. splendidus biovar II (Laboratory of Microbiology, Gent, Belgium: LMG 10952) and V. anguillarum (Collection of Pasteur Institute Paris, France: CIP 6336). The strains were confirmed to possess the key characteristics of the taxon (Alsina and Blanch, 1994).

\subsection{Vibrio isolation from spat groups suffering "summer mortality"}

In 1997 and 1998 moribund spat in groups suffering "summer mortality" syndrome were collected from the field and hatcheries (Table 1). Bacterial strains were obtained from flesh ground in sterile sea water and spread out over TCBS agar (thiosulfate citrate bile sucrose; Diagnostic Pasteur, Marne la Coquette, France) specific for the Vibrionaceae flora. Plates were incubated $24 \mathrm{~h}$ at $20^{\circ} \mathrm{C}$. Pure cultures were obtained by streaking and re-streaking on fresh media.

\subsection{Vibrio splendidus biovar II selection}

Vibrio splendidus biovar II strains were selected after the completion of a set of phenotypic tests: Gram staining reaction (Gram Kit; BioMérieux, Marcy l'Etoile, France); oxidase (Bactident oxidase; Merck, Darmstadt, Germany); respiratory activity (meat liver medium; Diagnostic Pasteur); and API 20E (BioMérieux) according to the manufacturer's instructions with the modifications suggested by MacDonnell et al. (1982), namely $2 \% \mathrm{NaCl}$ was added to the bacterial suspension.

According to Alsina and Blanch (1994), V. splendidus biovar II strains should be Gram negative, oxidase positive, facultative anaerobes; These strains were arginine dihydrolase, lysine decarboxylase and ornithine decarboxylase negative; and either (1) indole positive, gelatinase positive, no growth at $35^{\circ} \mathrm{C}$ and D-glucosamine negative or (2) indole negative, $\mathrm{NO} 2$ production positive, $\mathrm{L}$ arabinose negative, sucrose acidification negative.

\subsection{Phenotypic comparison}

The phenotypes of selected strains were compared using the following biochemical tests (Maury, 1987): gelatinase; urease; $\beta$-galactosidase; utilization of citrate; acetoin production (Voges-Proskauer reaction) ; nitrate reduction; $\mathrm{H}_{2} \mathrm{~S}$ production and acidification of lactose, glucose, arabinose, mannitol, and sucrose (API 20E, bioMérieux); glucose 
Table 1

Vibrio splendidus biovar II related strains isolated from moribond spat suffering of « summer mortality »syndrome and collected from field or hatcheries at the indicated period.

\begin{tabular}{|c|c|c|c|c|}
\hline Date & Origin & Site of sampling & Mortality (\%) & V. splendidus detected \\
\hline 1 July 1997 & Wild & Open sea (Charente) & 10 & TNEMC5 TNEMC8 \\
\hline 16 July 1997 & Wild & Open sea (Charente) & 30 & $\begin{array}{l}\text { TNEMD3 } \\
\text { TNEMD3' }\end{array}$ \\
\hline 16 September 1997 & Wild & Open sea (Charente) & 60 & $\begin{array}{l}\text { TNEMF6 } \\
\text { TNEMF8 }\end{array}$ \\
\hline 19 June 1998 & Hatchery & Open sea (Charente) & $\begin{array}{l}0 \\
\text { (strong smell) }\end{array}$ & $\begin{array}{l}\text { TNEMIII3 } \\
\text { TNEMIII4 } \\
\text { TNEMIII6 }\end{array}$ \\
\hline 11 July 1998 & Hatchery & Nursery & 10 & TNNIII7 \\
\hline 25 July 1998 & Hatchery & Nursery & 10 & TNNIV9 \\
\hline 22 September 1998 & Wild & Open sea (Bretagne) & 50 & $\begin{array}{l}\text { TNMB4 } \\
\text { TNMB5 } \\
\text { TNMB6 } \\
\text { TNMB7 }\end{array}$ \\
\hline
\end{tabular}

metabolism (MEVAG, Diagnostic Pasteur); respiratory metabolism (Meat liver medium; Diagnostic Pasteur); motility; $\mathrm{NaCl}$ requirement and tolerance $(0,6,8,10 \% \mathrm{w} / \mathrm{v})$; temperature tolerance $\left(4,20,35\right.$ and $\left.40{ }^{\circ} \mathrm{C}\right)$ in $1.5 \%(\mathrm{w} / \mathrm{v})$ peptone broth (Diagnostic Pasteur); presence of flagellae detected according to the method described by Mayfield and Inniss (1977); luminescence detected on marine agar (Diagnostic Pasteur) supplemented with $10 \%$ (v/v) glycerol.

\subsection{PCR-RFLP}

Bacterial strains were cultured in brain heart medium (Diagnostic Pasteur) for $8 \mathrm{~h}$ at $20^{\circ} \mathrm{C}$ and pelleted by centrifigution for $15 \mathrm{~min}$ at $5000 \mathrm{rpm}$. Lysis was performed overnight at $50{ }^{\circ} \mathrm{C}$ in $\mathrm{NaCl} 100 \mathrm{mM}$, EDTA $25 \mathrm{mM} \mathrm{pH} \mathrm{8,}$ SDS $0.5 \%$ and proteinase $\mathrm{K} 100 \mu \mathrm{g} \cdot \mathrm{ml}^{-1}(1 \mathrm{ml}$ of lysis buffer $/ 10^{8}$ bacteria). Nucleic acids were extracted using a standard phenol/chloroform protocol and precipitated with ethanol (Sambrook et al., 1989). Nucleic acids were dissolved in TE buffer and incubated with RNAse (100 $\mu \mathrm{g} \cdot \mathrm{ml}^{-1}$ ) at $37^{\circ} \mathrm{C}$ for $15 \mathrm{~min}$. DNA was again organic extracted, precipitated, and dissolved as described above.

PCR amplification of SSU rRNA, gyrB and $r p o D$ was done following the methods described previously (Yamamoto et Harayama, 1998 ; Lambert et al., 1998). Universal primers details are given in Table 2. PCR reactions were carried out in $50 \mu \mathrm{l}$ according to the standard conditions for Silver-star Taq DNA polymerase (Eurogentec, Seraing,
Belgium). After denaturation of DNA at $94{ }^{\circ} \mathrm{C}$ for $5 \mathrm{~min}, 30$ cycles were run with an MJ-Research thermocycler (Polylabo, Strasbourg, France) as follows: denaturation at $94{ }^{\circ} \mathrm{C}$ for $1 \mathrm{~min}$, annealing at $50{ }^{\circ} \mathrm{C}$ (SSU rRNA) or $58^{\circ} \mathrm{C}$ (gyrB and $r p o D$ ) for $1 \mathrm{~min}$, and elongation at $72{ }^{\circ} \mathrm{C}$ for $1 \mathrm{~min}$ per kbp. A final elongation step of $10 \mathrm{~min}$ at $72{ }^{\circ} \mathrm{C}$ was performed. Amplified products were analyzed electrophoretically on $1 \%$ agarose gels.

Polymorphisms among the PCR products were identified by cleavage with $\mathrm{MboI}$ or HhaI (Promega). The resulting restriction fragments were analyzed electrophoretically on $2 \%$ agarose gels.

\subsection{DNA/DNA hybridization}

Quantitative DNA/DNA hybridization was performed by a non-radioactive dot-blot method (Cardinali et al., 2000 ; Macian et al., 2001). DNA was extracted as described above with an additional step of ultracentrifugation through a cesium chloride gradient (Sambrook et al., 1989).

Probe preparation: DNA solutions were photo-labelled using the kit ECL RPN 3040 according to the manufacturer's instructions (Amersham).

Target preparation: DNAs were denatured in $\mathrm{NaOH} 1 \mathrm{~N}$ for 5 min at $4{ }^{\circ} \mathrm{C}$, neutralised in $\mathrm{Na}_{2} \mathrm{HPO}_{4} 1 \mathrm{~N}$, and deposited on a Hybond $\mathrm{N}$ membrane (Amersham) in 3 replicates (300 ng DNAs each) with a dot blot system (SRC 96 D

Table 2

Polymerase chain reaction, primers used in this study. bp : lengh in base pair; T: hybridization temperature given in ${ }^{\circ} \mathrm{C}$.

\begin{tabular}{|c|c|c|c|c|c|}
\hline Primer & Target & Sequence $\left(5^{\prime}-3^{\prime}\right)$ & $\mathrm{bp}$ & $\mathrm{T}\left({ }^{\circ} \mathrm{C}\right)$ & Position in $E$. coli \\
\hline AS dir & $16 \mathrm{~S}$ & AGAGTTTGATCATGGCTCAGA & 21 & 50 & $8-28$ \\
\hline $\mathrm{S} 17 \mathrm{rev}$ & $16 \mathrm{~S}$ & GTTACCTTGTTACGACTT & 18 & 50 & $1493-1509$ \\
\hline UP-1E & $g y r \mathrm{~B}$ & CAGGAAACAGCTATGACCAYGSNGGNGGNAARTTYRA & 37 & 58 & $335-355$ \\
\hline $\mathrm{APrU}$ & $g y r \mathrm{~B}$ & TGTAAAACGACGGCCAGTGCNGGRTCYTTYTCYTGRCA & 38 & 58 & $1482-1502$ \\
\hline $70 \mathrm{~F}$ & rpoD & ACGACTGACCCGGTACGCATGTAYATGMGNGARATGGGNACNGT & 44 & 58 & $300-324$ \\
\hline $70 \mathrm{R}$ & rpoD & ATAGAAATAACCAGACGTAAGTTNGCYTCNACCATYTCYTTYTT & 44 & 58 & $1128-1149$ \\
\hline
\end{tabular}


Minifold I, Schleider \& Schüll). DNAs were then fixed to the membrane by UV crosslinking.

Hybridization: Membranes were placed in hybridization bottles with $20 \mathrm{ml}$ of hybridization buffer (supplied by Amersham, ECL kit) and $50 \mu \mathrm{l}$ of denatured labelled probe were added. Hybridization was performed at $60^{\circ} \mathrm{C}$ for $20 \mathrm{~h}$. The membranes were washed twice $\left(15 \mathrm{~min}\right.$ at $\left.60^{\circ} \mathrm{C}\right)$ in SSC $1 \mathrm{X} / \mathrm{SDS} 0.1 \%$ and $10 \mathrm{~min}$ in SSC $0.5 \mathrm{X} / \mathrm{SDS} 0.1 \%$. Membranes were then blocked (liquid block supplied in the kit ECL RPN3040) and incubated with anti-fluoresceinHRP conjugate (Amersham). Finally detection of bound peroxidase was made using the ECL detection reagents (Amersham). Consequently, due to luminol oxidation, light was emitted in proportion to hybridization. Chemiluminescence was detected and quantified using a FLUOR-S ${ }^{\mathrm{TM}}$ Multil-imager BIO-RAD equipped with a Nikon $50 \mathrm{~mm}$ lens. Results were treated by the Multi-analyst software (BIO-RAD). Mean of chemiluminescence level (cpm. $\mathrm{mm}^{-2}$ ) reached by the 3 replicates of homologous DNAs was considered as $100 \%$ re-association rate, and level reached by herring sperm DNA as $0 \%$. The membranes were first hybridized with the labelled TNEMF6 probe. After reading the chemiluminescence, they were stripped (one rinse in SSC $5 \mathrm{X}$ and $2 \mathrm{~h}$ wash in SDS $0.1 \%$ solution previously heated to $100{ }^{\circ} \mathrm{C}$ ) and subsequently rehybridized using the labelled LMG 10952 probe.

\subsection{Experimental challenge}

Bacteria were grown at $20^{\circ} \mathrm{C}$ for $24 \mathrm{~h}$ in marine broth (Diagnostic Pasteur). Bacterial cultures were centrifuged 15 min at $5000 \mathrm{rpm}$ and harvested in sterile seawater at a concentration of 1-2 $10^{8} \mathrm{CFU}_{\mathrm{ml}}{ }^{-1}$ achieved by means of a spectrophotometer. The bacterial concentration was confirmed by enumeration on marine agar plates.

Adult clams, R. phillippinarum, originated from the SatMar nursery (St Just Luzac, France) and measured between $3-5 \mathrm{~cm}$. A volume of $100 \mu \mathrm{l}$ of bacterial suspension (i.e. $10^{7} \mathrm{CFU}$ ) was inoculated by injection into the adductor muscle. For each strain, a group of 50 animals was injected. A negative control consisted of a group of 50 clams injected with sterile seawater. The clams were held out of water overnight at $18^{\circ} \mathrm{C}$ and were then kept for one week in aerated seawater $(50$ clams in 2.51$)$ at $18^{\circ} \mathrm{C}$. Mortality was recorded twice a day. Water change and feeding with phytoplankton (Chaetoceros calcitrans) occurred every other day.

Oyster's spat, $C$. gigas, originated from the IFREMER nursery (La Tremblade, France) and measured $4-6 \mathrm{~cm}$. To anaesthetize and open valves, the spat were first kept for 2 $\mathrm{h}$ in seawater supplemented with $\mathrm{MgCl}_{2}$ at a final concentration of $50 \mathrm{~g} \cdot \mathrm{l}^{-1}$. A volume of $50 \mu \mathrm{l}$ of the bacterial suspension (i.e. $10^{7} \mathrm{CFU}$ ) was inoculated by injection into the adductor muscle. For each strain, a group of 36 animals was injected. Negative controls consisted of a group of 36 oysters injected with sterile seawater. Immediately after
Table 3

Phenotypic characteristics of Vibrio splendidus biovar II strains. Only the discriminant tests are mentioned. in grey TNEMF6 similar phenotype.

\begin{tabular}{lllllll}
\hline Strains & Indole & Citrate & ONPG & $4^{\circ} \mathrm{C}$ & Lactose & Mannitol \\
\hline TNEMC5 & + & + & + & + & - & + \\
TNEMC8 & + & + & - & + & + & - \\
TNEMD3 & + & + & + & + & - & + \\
TNEMD3 & + & + & + & - & - & + \\
TNEMF6 & + & + & - & - & - & + \\
TNEMF8 & + & + & + & + & + & + \\
TNEMIII3 & + & - & + & + & - & + \\
TNEMIII4 & + & + & - & - & - & - \\
TNEMIII6 & + & + & + & - & - & + \\
TNNIII7 & + & + & - & - & - & + \\
TNNIV9 & + & + & + & nd & - & + \\
TNMB4 & + & + & + & - & - & + \\
TNMB5 & + & + & - & - & - & + \\
TNMB6 & + & + & - & + & - & + \\
TNMB7 & + & + & + & + & - & nd \\
LMG 10952 & - & - & - & - & - & + \\
\hline
\end{tabular}

injection, oysters were transferred to aerated aquaria with seawater (36 oysters in 2.5 l) at $20^{\circ} \mathrm{C}$. Mortality was recorded daily. Feeding with phytoplankton (Chaetoceros calcitrans) occurred daily for one week.

\section{Results}

\subsection{Phenotyping}

Fourteen strains isolated from moribund oysters were selected and compared phenotypically to the pathogenic TNEMF6 strain (Table 1 and 3). Among 39 phenotypic tests used to compare the isolates, only 6 discriminated the selected strains: indole and citrate production, $\beta$-galactosidase production, growth at $4{ }^{\circ} \mathrm{C}$, lactose and mannitol acidification. Two strains out of 14, TNNIII7 and TNMB5, exhibited $100 \%$ similarity with TNEMF6 and were discriminated from LMG 10952 (the V. splendidus biovar II type culture) by indole and citrate production.

\subsection{PCR-RFLP}

Genotyping was carried out by PCR amplification of SSU rRNA, rpoD, and gyrB genes followed by digestion with $\mathrm{MboI}$ or HhaI. A schematic representation of fragment patterns obtained from each amplification and digestion is shown in Fig. 1 and results are summarized in Table 4. The number of patterns obtained was as follows : SSU rDNAMboI (2 patterns), SSU rDNA-HhaI (3 patterns), rpoDMboI (4 patterns), rpoD-HhaI (5 patterns), gyrB-MboI (6 patterns), gyrB-HhaI (10 patterns). Thus, an increased discrimination between strains was obtained by using respectively SSU rDNA - rpoD - gyrB and MboI-HhaI in PCR RFLP analysis. The pathogenic strain, TNEMF6, has a distinct genotype (BABBBE). Only TNNIII7 shared four patterns with TNEMF6 (SSU rDNA-MboI, HhaI, rpoDMboI and gyrB-Hhal). 
SSU rDNA MboI

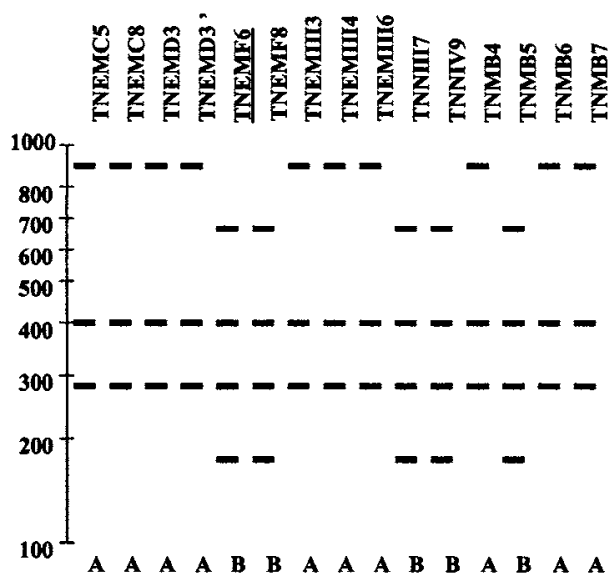

rpoD MboT

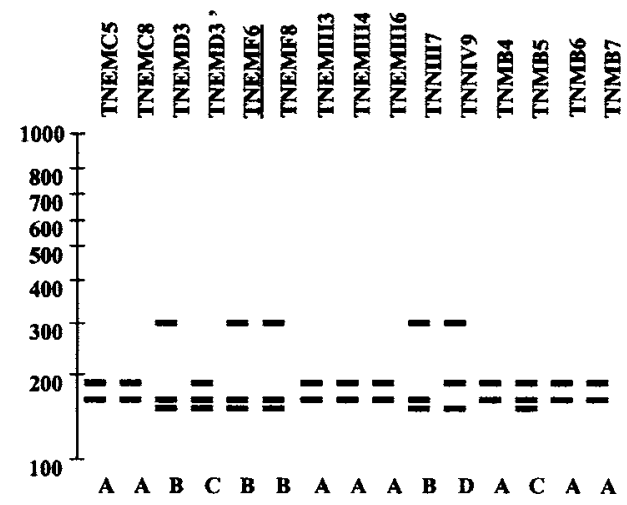

gyrB MboI

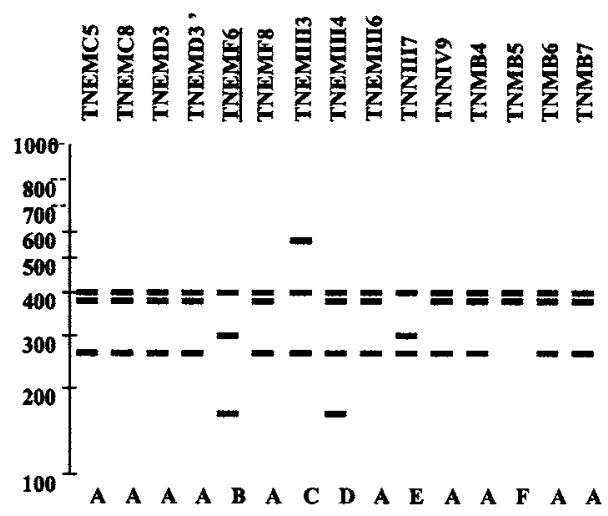

\section{SSU rDNA HhaI}

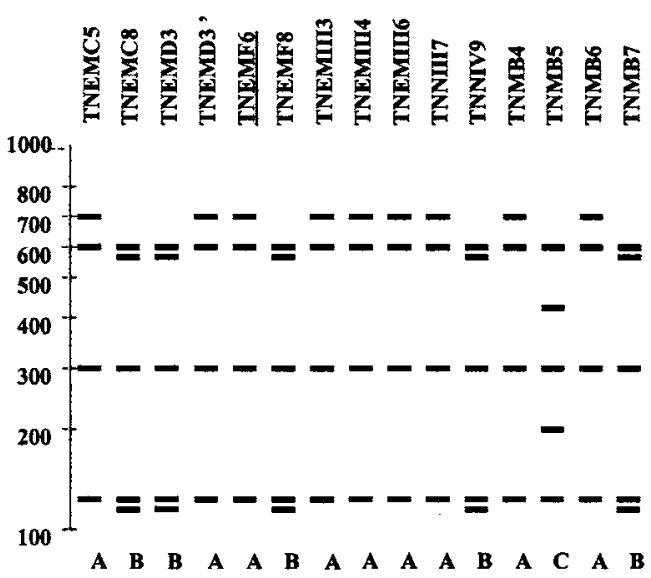

rpoD HhaI

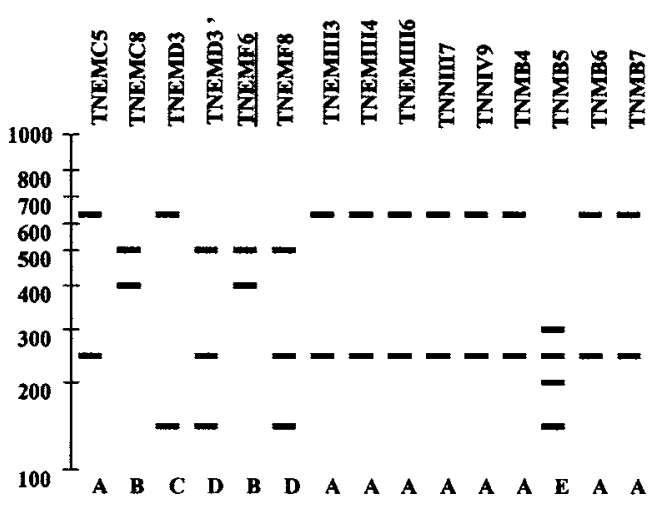

gyrB HhaI

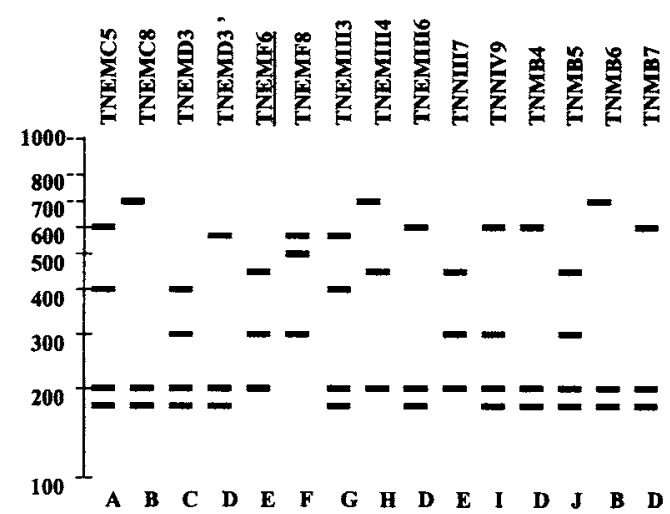

Fig. 1. Restriction fragment patterns of SSU rRNA, $r p o D$ and $g y r B$ genes digested by $M b o I$ and HhaI. Restriction fragments shorter than 100 base pairs were not used for analysis. Clustering per PCR-RFLP and strain are presented in Table 4. 
Table 4

Summary of restriction fragment patterns of SSU ribosomal sub unit rRNA, rpoD, and gyrB amplicons digested by $M b o I$ and HhaI. * strains not discriminated by this battery of tests; in grey TNEMF6 similar patterns.

\begin{tabular}{lllllll}
\hline Strains & $16 \mathrm{~S}$ & $16 \mathrm{~S}$ & RpoD & RpoD & GyrB & GyrB \\
& MboI & HhaI & MboI & HhaI & MboI & Hhal \\
\hline TNEMC5 & A & A & A & A & A & A \\
TNEMC8 & A & B & $\mathbf{A}$ & $\mathbf{B}$ & $\mathbf{A}$ & $\mathbf{B}$ \\
TNEMD3 & $\mathbf{A}$ & $\mathbf{B}$ & $\mathbf{B}$ & $\mathbf{C}$ & $\mathbf{A}$ & $\mathbf{C}$ \\
TNEMD3 & $\mathbf{A}$ & $\mathbf{A}$ & $\mathbf{C}$ & $\mathbf{D}$ & $\mathbf{A}$ & $\mathbf{D}$ \\
TNEMF6 & $\mathbf{B}$ & $\mathbf{A}$ & $\mathbf{B}$ & $\mathbf{B}$ & $\mathbf{B}$ & $\mathbf{E}$ \\
TNEMF8 & $\mathbf{B}$ & $\mathbf{B}$ & $\mathbf{B}$ & $\mathbf{D}$ & $\mathbf{A}$ & $\mathbf{F}$ \\
TNEMIII3 & $\mathbf{A}$ & $\mathbf{A}$ & $\mathbf{A}$ & $\mathbf{A}$ & $\mathbf{C}$ & $\mathbf{G}$ \\
TNEMIII4 & $\mathbf{A}$ & $\mathbf{A}$ & $\mathbf{A}$ & $\mathbf{A}$ & $\mathbf{D}$ & $\mathbf{H}$ \\
TNEMIII6 & $\mathbf{A}$ & $\mathbf{A}$ & $\mathbf{A}$ & $\mathbf{A}$ & $\mathbf{A}$ & $\mathbf{D} *$ \\
TNNIII7 & $\mathbf{B}$ & $\mathbf{A}$ & $\mathbf{B}$ & $\mathbf{A}$ & $\mathbf{E}$ & $\mathbf{E}$ \\
TNNIV9 & $\mathbf{B}$ & $\mathbf{B}$ & $\mathbf{D}$ & $\mathbf{A}$ & $\mathbf{A}$ & $\mathbf{J}$ \\
TNMB4 & $\mathbf{A}$ & $\mathbf{A}$ & $\mathbf{A}$ & $\mathbf{A}$ & $\mathbf{A}$ & $\mathbf{D} *$ \\
TNMB5 & $\mathbf{B}$ & $\mathbf{C}$ & $\mathbf{C}$ & $\mathbf{E}$ & $\mathbf{F}$ & $\mathbf{K}$ \\
TNMB6 & $\mathbf{A}$ & $\mathbf{A}$ & $\mathbf{A}$ & $\mathbf{A}$ & $\mathbf{A}$ & $\mathbf{B}$ \\
TNMB7 & $\mathbf{A}$ & $\mathbf{B}$ & $\mathbf{A}$ & $\mathbf{A}$ & $\mathbf{A}$ & $\mathbf{D}$
\end{tabular}

\subsection{DNA/DNA hybridization}

Five strains (TNEMF6, TNNIII7, TNMB5, LMG 10952, CIP 6336) were submitted to DNA/DNA hybridization (Table 5). When using TNEMF6 DNA as a probe, TNNIII7 shared $92.5 \%$ homology and LMG $1095280.4 \%$. The use of LMG 10952 DNA as a probe corrooborated these results: TNNIII7 shared $84.4 \%$ and TNEMF6 $72.7 \%$. On the opposite, TNMB5 showed only $42.3 \%$ homology with TNEMF6 probe and $46.3 \%$ with LMG 10952 probe. The DNA/DNA hybridization studies suggested close relationship among 3 strains, TNEMF6, TNNIII7 and LMG 10952. The outgroup represented by $V$. anguillarum (CIP 6336) exhibited 27.7\% homology with TNEMF6 and 30.3\% homology with LMG 10952.

\subsection{Experimental challenge}

Virulence of TNEMF6 and TNNIII7 was compared following injection into $C$. gigas spat and $R$. philippinarum. Two series of experiments were conducted. Clams were more sensitive to injection of sterile sea water and Vibrio than oysters. In $C$. gigas, TNEMF6 induced mortality (25\%)

Table 5

Percentage of DNA/DNA hybridization with DNA of TNEMF6 and LMG 10952 as probes for Vibrio splendidus strains that exhibit strong homology to the pathogenic strain.

\begin{tabular}{lll}
\hline & Probe & \\
\hline Target & $\begin{array}{l}\text { TNEMF6 } \\
(\%)\end{array}$ & $\begin{array}{l}\text { LMG 10952 } \\
(\%)\end{array}$ \\
\hline TNEMF6 & 100 & 72.7 \\
LMG 10952 & 80.4 & 100 \\
TNNIII7 & 92.5 & 84.4 \\
TNMB5 & 42.3 & 46.3 \\
CIP 6336 & 27.7 & 30.3 \\
\hline
\end{tabular}

after 4 days in only one experiment. In clams, TNEMF6 induced a higher rate of cumulative mortality in both experiment (81 and 53\%). TNNIII7 appeared to be an avirulent strain in both hosts (Fig. 2).

\section{Discussion}

We compared strains isolated during mortality events to TNEMF6 biochemically and genomically. Although 14 strains were biochemically identified as Vibrio splendidus biovar II, only one, TNNIII7, was similar to TNEMF6. DNA/DNA hybridization confirmed that these two strains belong to the same species; however, TNNIII7 did not appear to be virulent. Although, the TNMB5 strain was $100 \%$ similar phenotypically to TNEMF6, it did not belong to the same species according to DNA/DNA hybridization. Therefore, phenotyping is not sufficient to identify Vibrio splendidus biovar II. A clarification of Vibrio splendidus taxonomy, based on a polyphasic approach, appears to be necessary (Waechter et al., 2002). Here we have shown that PCR-RFLP, based on the amplification of different genes of phylogenetic interest and cleavage with various restriction enzymes may be a useful tool in investigating Vibrio splendidus biovar II biodiversity and can be used to study distribution of these strains in environment.

The strain TNEMF6 was isolated from spat groups suffering a high rate of mortality. We do not yet know if the vibriosis observed in September 1997 (date of TNEMF6 isolation) was an epiphenomenon or if the strain is a causative factor in other mortality events but has gone undetected due to the sampling methods. Actually, due to the size of the animals, only the spat flesh was ground. The pathogenic strain can be masked by Vibrio harboured in the digestive tract, where they constitute the majority of bacteria (Prieur, 1982). Furthermore our sampling excluded bacteria attached to the shell surface although different authors have demonstrated the localisation of pathogenic Vibrio in compartments outside the soft tissues (Elston and Leibovitz, 1980; Elston et al., 1982; Paillard and Maes, 1990). GyrB PCR/RFLP pattern of TNEMF6 strain is unique among all tested strains. $G y r B$ gene sequencing and alignment of a Vibrio collection are in progress in order to develop molecular tools to diagnose TNEMF6. Therefore, substancial advances can be made on genetic turf in detecting the TNEMF6 strain in order to associate or not this strain with oysters summer mortality.

However, our studies of such genes did not lead to the identification of pathogenicity. Here, TNEMF6 and TNNIII7 were phenotypically and genotypically very similar, whereas their virulence was markedly different. Therefore, we do not yet have any phenotypic or genotypic feature to distinguish pathogenic $V$. splendidus strains from nonpathogenic ones. Vibrio splendidus is widely distributed in marine ecosystems (Nealson et al., 1993; Farto et al., 1999; Macian et al., 2000). Different strains have been associated 


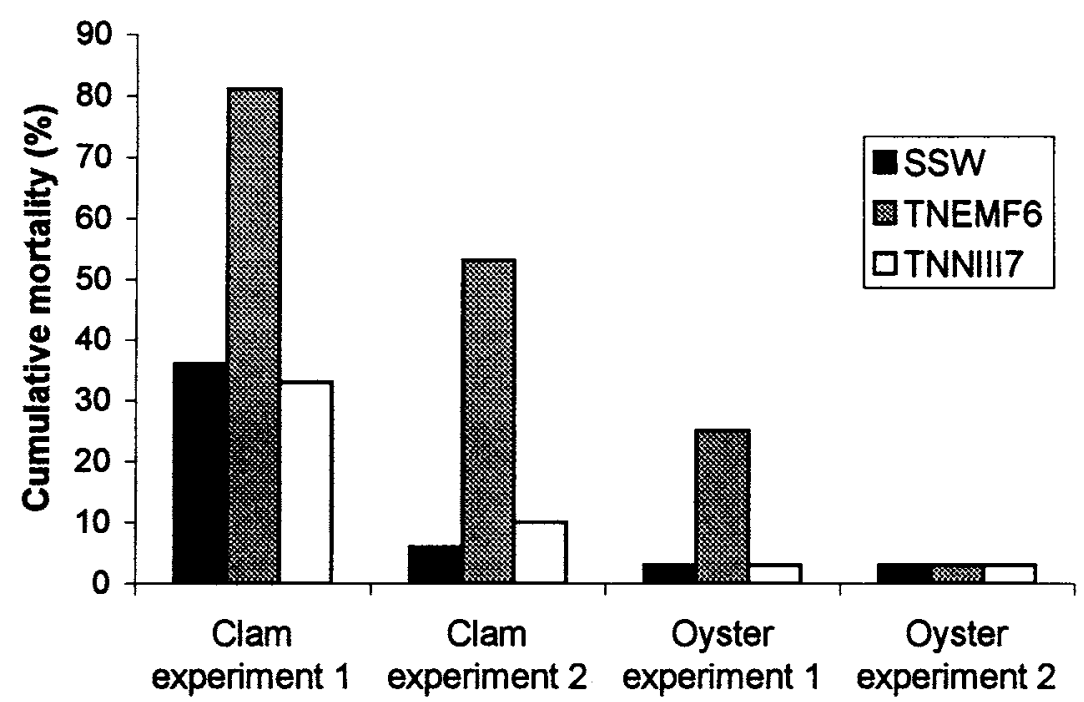

Fig. 2. Comparison of bacterial virulence measured as cumulative percentage mortality induced by experimental challenge 4 days after injection of TNEMF6 or TNNIII7 to Crassostrea gigas spat and clam Ruditapes philippinarum. Sterile sea water (SSW) was injected as a negative control.

with mortalities of $C$. gigas larvae (Sugumar et al., 1998), scallops larvae Pecten maximus (Nicolas et al., 1996), and fish larvae (Gatesoupe et al., 1999). A wide range of virulence among strains from the same species has been observed by experimental exposure on different animal models. Until now, the virulence of a strain has been assessed by experimental challenge, but this approach is time consuming and results may vary from one trial to another. Further development of this work should include the search for diagnostic tools specific of virulence factors. For example, the virulent TNEMF6 and avirulent TNNIII7 strains belonging to the same species could be compared in vitro to characterise virulence mechanisms. Genes involved could be screened by using degenerated oligonucleotides or genomic substraction.

Other field studies indicated a complex etiology of summer mortalities with several factors implicated (Goul letquer et al., 1998). Therefore, it can be assumed that the background rate of mortality due to environmental conditions, physiology and genetics, can be moderated by an infectious agent which could play a role of opportunist rather than pathogen. Until now, only 3 infectious agents with potential pathogenicity have been detected in oyster spat groups experiencing summer mortality: (1) herpes-like virus (Renault et al., 1994; 1995), (2) Vibrio splendidus similar to SCB8 strain (Lacoste et al., 2001) and (3) V. splendidus biovar II (Waechter et al., 2002). The two strains of Vibrio splendidus induced mortalities of $C$. gigas spat under conditions of experimental challenge. Therefore, even if these infectious agents can not yet be considered as etiological agents of summer mortality, they can be used in experimental challenge to study the effect of environmental conditions, physiology and genetic factors on bacterial virulence and host response.

\section{Acknowledgements}

This study was carried out with financial assistance from Grainocean society (contract 97/5211243) and the Community Reference Laboratory (CRL). The authors acknowledge Jean François Auvray (SATMAR) for providing clams. The authors also thank Gwenaelle Choquet and Raphael Brizard for their technical assistance and Professor Brian Austin for critically reading the manuscript.

\section{References}

Alsina, M., Blanch, A.R., 1994. A set of keys for biochemical identification of environmental Vibrio species. J. Appl. Bacteriol. 76, 79-85.

Brown, C., 1981. A study of two shellfish-pathogenic Vibrio strains isolated from a Long Island hatchery during a recent outbreak of disease. J. Shell Res. 1, 83-87.

Cardinali, G., Liti, G., Martini, A., 2000. Non-radioactive dot-blot DNA reassociation for unequivocal yeast identification. Int. J. Syst. Evol. Microbiol. 50, 931-936.

Dungan, C.F., Elston, R.A., Schiewe, M.H., 1989. Evidence for colonization and destruction of hinge ligaments in cultured juvenile Pacific oysters (Crassostrea gigas) by cytophaga-like bacteria. Appl. Environ. Microbiol. 55, 1128-1135.

Elston, R.A., Leibovitz, L., 1980. Pathogenesis of experimental vibriosis in larval American oysters, Crassostrea virginica. Can. J. Fish Aquat. Sci. 37, 964-978.

Elston, R., Elliot, E.L., Colwell, R.R., 1982. Conchiolin infection and surface coating Vibrio: shell fragility, growth depression and mortality in cultured oysters and clams, Crassostrea virginica, Ostrea edulis and Mercenaria mercenaria. J. Fish Dis. 5, 265-284.

Elston, R.A., Beattie, J.H., Friedman, C., Hedrick, R., Kent, M.L., 1987. Pathology and significance of fatal inflamatory bacteraemia in the Pacific oyster. Crassostrea gigas Thünberg. J. Fish Dis. 10, 121-132.

Farto, R., Montes, M., Perez, M.J., Nieto, T.P., Larsen, J.L., Pedersen, K., 1999. Characterization by numerical taxonomy and ribotyping of Vibrio 
splendidus biovar I and Vibrio scophthalmi strains associated with turbot cultures. J. Appl. Microbiol. 86, 796-804.

Fox, G.E., Wisotzkey, J.D., Jurtshuk, P.J., 1992. How close is close: 16S rRNA sequence identity may not be sufficient to guarantee species identity. Int. J. Syst. Bacteriol. 42, 166-170.

Gatesoupe, F.J., Lambert, C., Nicolas, J.L., 1999. Pathogenicity of Vibrio splendidus strains associated with turbot larvae, Scophthalmus maximus. J. Appl. Microbiol. 87, 757-763.

Goulletquer, P., Soletchnik, P., Le Moine, O., Razet, D., Geairon, P., Faury, N., Taillade, S., 1998. Summer mortality of the Pacific cupped oyster Crassostrea gigas in the Bay of Marennes Oléron (France). ICES Mariculture Committee CM1998/CC. pp. 14-21.

Hada, H.S., West, P.A., Lee, J.V., Stemmler, J., Colwell, R.R., 1984. Vibrio tubiashii sp. nov., a pathogen of bivalve mollusks. Int. J. Syst. Bacteriol. $34,1-4$.

Jeffries, V.E., 1982. Three Vibrio strains pathogenic to larvae of Crassostrea gigas and Ostrea edulis. Aquaculture 29, 201-226.

Lacoste, A., Jalabert, F., Malham, S., Cueff, A., Gélébart, F., Cordevant, C., Lange, M., Poulet, S.A., 2001. A Vibrio splendidus strain is associated with summer mortality of juvenile oysters Crassostrea gigas in the Bay of Morlaix (North Brittany. France. Dis. Aquat. Org. 46, 139-145.

Lambert, C., Nicolas, J.L., Cilia, V., Corre, S., 1998. . Vibrio pectenicida sp. nov. a pathogen of scallop (Pecten maximus) larvae. Int. J. Syst. Bacteriol. 48, 481-487.

MacDonnell, M.T., Singleton, F.L., Hood, M.A., 1982. Diluent composition for use of API 20E in characterising marine and estuarine bacteria. Appl. Environ. Microbiol. 44, 423-427.

Macian, M.C., Garay, E., Gonzalez-Candelas, F., Pujalte, M.J., Aznar, R., 2000. Ribotyping of Vibrio populations associated with cultured oysters (Ostrea edulis). Syst. Appl. Microbiol. 23, 409-417.

Macian, M.C., Ludwig, W., Aznar, R., Grimont, P.A., Schleifer, K.H., Garay, E., Pujalte, M.J., 2001. Vibrio lentus sp. nov., isolated from Mediterranean oysters. Int. J. Syst. Evol. Microbiol. 51, 1449-1456.

Maury, M., 1987. Milieux et réactifs de laboratoire. Diagnostics Pasteur. $3^{\text {rd }}$ ed. Paris, France.

Mayfield, C.I., Inniss, W.E., 1977. A rapid, simple method for staining bacterial flagella. Can. J. Microbiol. 23, 1311-1313.

Nealson, K.H., Wimpee, B., Wimpee, C., 1993. Identification of Vibrio splendidus as a member of the planktonic luminous bacteria from
Persian Gulf and Kuwait region with LuxA probes. Appl. Environ. Microbiol. 59, 2684-2689.

Nicolas, J.L., Corre, S., Gauthier, G., Robert, R., Ansquer, D., 1996. Bacterial problems associated with scallop Pecten maximus larval culture. Dis. Aquat. Org 27, 67-76.

Paillard, C., Maes, P., 1990. Etiologie de la maladie de l'anneau brun chez Tapes philippinarum : pathogénicité d'un Vibrio sp. C.R. Acad. Sci. Paris 310, 15-20.

Prieur, D., 1980. The microflora of the digestive tract of marine bivalves: experimental study of the mussel, Mytilus edulis. International Malagological Congress. Perpignan, France.

Renault, T., Cochennec, N., Le Deuff, R.M., Chollet, B., 1994. Herpes-like virus infecting Japanese oyster (Crassostrea gigas) spat. Bull. Eur. Assoc. Fish Pathol 14, 64-65.

Renault, T., Le Deuff, R.M., Cochennec, N., Chollet, B., Maffart, P., 1995. Herpes-like viruses associated with high mortality levels in larvae and spat of pacific oysters, Crassostrea-gigas a comparative-study, the thermal effects on virus detection in hatchery-reared larvae, reproduction of the disease in axenic larvae. Vet. Res. 26, 539-543.

Sambrook, J., Fritsch, E.F., Maniatis, T., 1989. Molecular cloning: a laboratory manual. $2^{\text {nd }}$ ed. Cold Spring Harbor, N.Y.

Stackebrandt, E., Goebel, B.M., 1994. Taxonomic note: A place for DNA-DNA reassociation and 16S rRNA sequence analysis in the present species definition in bacteriology. Int. J. Syst. Bacteriol. 44, 846-849.

Sugumar, G., Nakai, T., Hirata, Y., Matsubara, D., Muroga, K., 1998. Vibrio splendidus biovar II as the causative agent of bacillary necrosis of Japanese oyster Crassostrea gigas larvae. Dis. Aquat. Org. 33, $111-118$.

Waechter, M., Le Roux, F., Nicolas, J.L., Marissal, E., Berthe, F., 2002. Caractérisation de bactéries pathogènes de naissains d'huître creuse Crassostrea gigas. C. R. Acad. Sci., Sér. III 325, 231-238.

Yamamoto, S., Harayama, S., 1998. Phylogenetic relationships of pseudomonas putida strains deduced from the nucleotide sequences of gyrB, $r p o D$ and $16 \mathrm{~S}$ rRNA genes. Int. J. Syst. Bacteriol. 48, 813-819. 